\title{
USPEH NESTRANKARSKIH KANDIDATOV NA LOKALNIH VOLITVAH 2006
}

\author{
Boštjan Rogelj \\ Oddelek za geografijo Filozofske fakultete Univerze v Ljubljani, Aškerčeva cesta 2, \\ SI - 1000 Ljubljana, Slovenija \\ e-mail: bostjan.rogelj@ff.uni-lj.si
}

Izvirni znanstveni članek

COBISS 1.01

\section{Izvleček}

Večina novinarskih analiz rezultatov lokalnih volitev 2006, poudarja velik uspeh nestrankarskih županskih kandidatov in svetniških list. S pričujočo raziskavo smo želeli ugotoviti, ali omenjena trditev drži, ali pa je le posledica nepričakovano dobrih rezultatov nekaterih neodvisnih kandidatov in list v posameznih občinah. V ospredju našega zanimanja so bila naslednja vprašanja: Ali smo bili dejansko priče pomembnemu preobratu v slovenskem političnem prostoru? Ali se lokalne volitve 2006 glede zastopanosti nestrankarskih list in županov bistveno razlikujejo od prejšnjih volitev? Ali obstajajo pomembne regionalne razlike med posameznimi predeli Slovenije glede zastopanosti nestrankarskih županov in svetniških list?

Ključne besede: lokalne volitve, geografija volitev, stranke, nestrankarski kandidati

\section{SUCCESS OF NONPARTY CANDIDATES ON LOCAL ELECTIONS 2006 IN SLOVENIA}

\begin{abstract}
According to many commentators, the most important characteristic of 2006 local elections in Slovenia is unexpected success of independent (nonparty) municipality council lists and mayor candidates. In our research, we wanted to find out if these statements are correct or are they just the effect of unexpected success of nonparty candidates and municipality council lists in specific municipalities. Three questions are especially important to us: Are we really witnessing important shift on Slovenian political space? Are the results of 2006 local election really distinguishing form previous election, concerning the success of nonparty municipality council lists and mayor candidates? Are there any essential differences between different regions regarding representation of nonparty mayors and municipality councilors?
\end{abstract}

Key words: local elections, electoral geography, parties, nonparty candidates. 


\section{UVOD}

Lokalne volitve 2006 so bile četrte po reformi komunalnega sistema leta 1994. Volitve so potekale v 210 občinah. V sedemnajstih občinah - nastalih s preoblikovanjem občinske mreže leta 2006 - so župane in občinske svetnike volili prvič.

Volitve županov in članov občinskih svetov ureja zakon o lokalnih volitvah. Tako svetniki kot župani se volijo na neposrednih, tajnih volitvah. Medtem ko se župane voli po večinskem sistemu, se občinski svetniki, glede na velikost občine volijo po proporcionalnem ali večinskem sistemu.

Glede na predlagatelja lahko kandidate za župane in občinske svetnike razdelimo v dve skupini. Prva so strankarski kandidati. Njihovi predlagatelji so ponavadi občinski odbori političnih strank. Strankarske kandidate lahko kandidirajo posamične stranke ali pa koalicija strank. Druga skupina so nestrankarski kandidati. V nasprotju s strankarskimi kandidati, ki za kandidiranje potrebujejo le soglasje oziroma nominacijo stranke, morajo nestrankarski kandidati za svojo kandidaturo pridobiti soglasje določenega števila volivcev v volilni enoti, v kateri kandidirajo. Zakon o lokalnih volitvah (ZLV), ki je bil sprejet leta 1993, je v 68. členu določal, da morajo nestrankarski kandidati zbrati podpise najmanj $2 \%$ volivcev v volilni enoti, vendar ne več kot 2500 podpisov. Omenjeni člen zakona je Ustavno sodišče RS leta 2006 razveljavilo, saj je po njegovem mnenju kršilo načelo enakosti pred zakonom in nestrankarske kandidate postavljalo v neenakopraven položaj. V isti odločbi je Ustavno sodišče določilo, da je treba za vložitev nestrankarske kandidature na lokalnih volitvah do sprejetja drugačne ureditve zbrati podpise petnajstih volivcev. $S$ to odločbo se je močno olajšalo vlaganje nestrankarskih kandidatur, še posebno v občinah z večjim številom prebivalcev.

Lokalne volitve 2006 so postregle z nekaterimi presenetljivimi rezultati. Glavna ugotovitev večine komentatorjev je bila, da so neodvisni oz. nestrankarski kandidati in liste s svojim uspehom resno omajale vlogo in moč političnih strank. Kot primer so navajali presenetljiv uspeh Zorana Jankovića in njegove nestrankarske liste v Ljubljani. Jankoviću je že v prvem krogu uspelo, s prepričljivo večino (62,99\% glasov) zasesti županski položaj, njegova lista pa je dobila absolutno večino v ljubljanskem mestnem svetu ( 23 od 45 svetniških mest). Uspehi drugih nestrankarskih kandidatov so bili redkeje ali pa sploh niso bili omenjeni. Dejstvo, da je teza o velikem uspeh nestrankarskih kandidatov skoraj vselej temeljila na rezultatih volitev v Ljubljani, nas je spodbudila k resnejši in popolnejši analizi uspeha nestrankarskih kandidatov in list. Zanimalo nas je, kako uspešni so bili nestrankarski kandidati oziroma ali resnično lahko govorimo o preobratu $\mathrm{v}$ slovenskem političnem prostoru. $\mathrm{V}$ ta namen smo rezultate primerjali z lokalnimi volitvami 2002. Poleg tega nas je zanimalo, ali obstajajo pomembne regionalne razlike v uspešnosti nestrankarskih kandidatov. Poleg analize volilnih rezultatov po posameznih statističnih regijah smo ugotavljali razlike med mestnimi in ne-mestnimi občinami, med velikimi in majhnimi ter »novimi« in »starimi« občinami.

Analiza rezultatov nestrankarskih kandidatov in list na lokalnih volitvah 2006 je razdeljena na tri dele. V prvem obravnavamo nekatere teoretične in metodološke probleme povezane, $z$ analizo lokalnih volitev. V drugem delu je predstavljena analiza županskih volitev. Tretji del tvori analiza volitev v občinske oziroma mestne svete.

Osnovni podatki za analizo so rezultati lokalnih volitev 2006, ki so bili pridobljeni na internetni strani Lokalne volitve 2006 (http://volitve.gov.si/lv2006/index.html). Podatki 
o lokalnih volitvah 2002 so pridobljeni s internetnih strani Statističnega urada Republike Slovenije (http://www.stat.si/).

\section{METODOLOGIJA}

Pred začetkom podrobnejše analize je treba razjasniti termin nestrankarske liste oziroma nestrankarski kandidati. Glavna razlika med strankarskim in nestrankarskim kandidatom na lokalnih volitvah je v načinu kandidiranja. Medtem ko strankarske kandidate predlagajo politične stranke, ki so uradno registrirane v Republiki Sloveniji, nestrankarske kandidate predlagajo skupine volivcev. Namesto termina nestrankarski se pogosto - še posebno v medijih - uporablja termin neodvisni. Uporaba slednjega je neustrezna. Prvič zato, ker je najpomembnejša razlika med strankarskimi in nestrankarskimi kandidati $v$ načinu kandidiranja, ne pa v njihovi politični odvisnosti oziroma neodvisnosti. Drugič pa zato, ker predvideva, da so vsi nestrankarski kandidati politično neodvisni, kar pa je seveda ne drži. Tudi na zadnjih volitvah je bilo več kandidatov, ki so bili nominalno nestrankarski kandidati - njihovo kandidaturo je vložila skupina volivcev -, dejansko pa so imeli močno podporo ene ali več političnih strank. Najbolj znan primer je dr. France Arhar, ki ga je uradno kandidirala nestrankarska lista Zbor za Ljubljano, dejansko pa so tako finančno kot politično njegovo kandidaturo podpirale tri parlamentarne stranke. Zaradi omenjenih razlogov se $\mathrm{v}$ članku dosledno uporablja termin nestrankarski, ki je ustreznejši od termina neodvisni.

Poleg nestrankarskih kandidatov, ki morajo za svojo kandidaturo zbrati podpise vsaj petnajstih volivcev v volilni enoti v kateri kandidirajo, na volitvah nastopajo tudi različne politične stranke. Za potrebe analize smo strankarske kandidate razdelili v tri skupine, in sicer parlamentarne, neparlamentarne in koalicijske. Razlikovanje med parlamentarnimi in neparlamentarnimi se na prvi pogled zdi nesmiselno, vendar pa je natančnejša analiza pokazala bistvene razlike med omenjenima skupinama. Za Slovenijo je značilna relativna stabilnost političnega prostora. Politični prostor na državni ravni, vse od sredine 90. let naprej obvladuje manjše število strank. Rezultati državnozborskih volitev po letu 1991 to potrjujejo. Glavna prednost parlamentarnih strank je v tem, da nenehno nastopajo v medijih, zaradi česar so med volivci veliko bolj prepoznavne kot neparlamentarne. Poleg tega imajo bolj razvejeno mrežo regionalnih in občinskih odborov, kar jim omogoča delovanje na ozemlju celotne države. Nasprotno le redke neparlamentarne stranke delujejo na področju celotne države, večina je bolj regionalno oziroma lokalno usmerjenih. Regionalno in lokalno usmerjene stranke bi lahko razdelili v dve skupini. V prvi so tiste, ki že v imenu izkazujejo svojo regionalno oz. lokalno pripadnost, $\mathrm{v}$ drugi pa so tiste, ki jo glede na ime ne moremo opredeliti kot regionalne, vendar delujejo le $\mathrm{v}$ nekaterih regijah (ponavadi $\mathrm{v}$ regiji, kjer je sedež stranke). Tipični predstavniki prve skupine so Zveza za Primorsko, Zveza za Dolenjsko, Piran je naš, Mladi za Izolo itd... Medtem, ko v drugo skupino lahko uvrstimo stranke Lista za čisto pitno vodo, Zveza poštenih ljudi Slovenije, Republikanci Slovenije, itd... Zaradi naštetega je politična moč neparlamentarnih strank pogosto omejena na manjši prostor - določeno občino oziroma regijo. Iz povedanega je razvidno, da je večina - ne pa vse - neparlamentarnih strank po načinu delovanja bliže nestrankarskim listam, čeprav so formalnopravno organizirane kot politične stranke. 
Koalicijski kandidati pomenijo tretjo obliko strankarskega kandidiranja županov in svetnikov na lokalnih volitvah. V tem primeru kandidaturo skupaj vložita dve ali več politični stranki. Na tem mestu je treba opozoriti na razliko med koalicijsko kandidaturo in koalicijsko podporo. Kandidat je lahko delež podpore koalicije strank, čeprav ga je kandidirala ena sama stranka. Medtem ko je ugotavljanje koalicijskih kandidatur zelo preprosto, je ugotavljanje koalicijske podpore veliko težje. Koalicijska podpora je lahko bolj ali manj jasna - stranka lahko podpre nekoga že s tem, da ne predlaga svojega protikandidata.

Za lokalne volitve v Sloveniji je značilno, da so koalicijske kandidature redke, čeprav se župani pa tudi del občinskih svetnikov voli po večinskem sistemu, ki spodbuja k oblikovanju koalicij. Glavni razlog za takšno stanje lahko iščemo v velikem rivalstvu med posameznimi strankami. Poleg tega pa se moramo zavedati prej omenjene razlike med koalicijsko kandidaturo in podporo. Število slednjih je veliko večje, še posebno pri drugem krogu županskih volitev. Druga značilnost koalicijskih kandidatur je, da ni pravila katere stranke oblikujejo koalicijo. Koalicije se oblikujejo med parlamentarnimi in neparlamentarnimi strankami, med pozicijskimi in opozicijskimi strankami (glede na položaj strank na državni ravni), med "levimi” in "desnimi” strankami.

\section{VOLITVE ŽUPANOV}

Volitve županov potekajo po sistemu absolutne večine - kandidat mora za izvolitev dobiti absolutno večino veljavnih glasov. Če v prvem krogu noben izmed kandidatov ne dobi absolutne večine, se opravi drugi krog volitev, v katerega se uvrstita kandidata $\mathrm{z}$ največjim številom glasov (Zakon o lokalnih volitvah).

\section{Kandidiranje}

Na lokalnih volitvah 2006 se je za 210 županskih mest potegovalo 847 kandidatov. Največ kandidatov se je za županski stolček potegovalo v Ljubljani (16), Mariboru (14), Radencih (11) in Kopru (10). V šestnajstih občinah je kandidiral le po en kandidat (glej karto 1). Statistična analizo je pokazala, da obstaja srednje močna povezanost med velikostjo občin in številom kandidatov. Praviloma v večjih občinah (glede na število prebivalcev) kandidira več kandidatov kot v manjših, obstajajo pa tudi izjeme. Tako sta v mestni občini Slovenj Gradec (16779 prebivalcev) kandidirala le dva kandidata, nasprotno pa je v občini Logatec (3356 prebivalcev) kandidiralo devet kandidatov.

Glede na predlagatelja smo kandidate razdelili v štiri skupine: kandidati parlamentarnih strank, neparlamentarnih strank, strankarskih koalicij in nestrankarske kandidate. Največ kandidatov za župane so predlagale parlamentarne stranke, in sicer 528 (glej tabelo 2). K temu številu lahko prištejemo še vse koalicijske kandidate, saj so kar 30 koalicijskih kandidatov (oziroma 69,8\%) predlagale koalicije parlamentarnih strank, preostalih 13 kandidatov so kandidirale koalicije parlamentarnih in neparlamentarnih strank.

Neparlamentarne stranke so kandidirale 107 kandidatov v 64 občinah (30,5\% vseh občin). Največ kandidatov neparlamentarnih strank je bilo v treh mestnih občinah Ljubljani (10), Mariboru (8) in Kopru (5). Zanimiva je odsotnost koalicij neparlamentarnih strank, saj niti enega župana ni kandidirala koalicija neparlamentarnih strank. 
Tabela 1: Vpliv velikosti občin na število županskih kandidatov

Table 1: Influence of the size of municipalities on the number of candidates for mayors

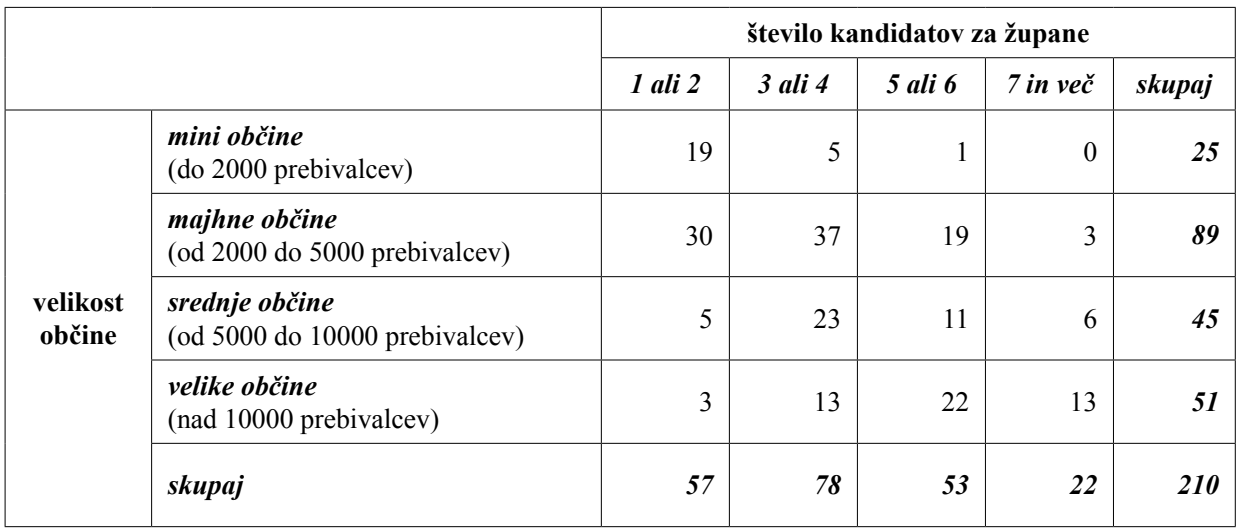

Tabela 2: Število županskih kandidatov in izvoljenih županov glede na predlagatelja Table 2: Number of candidates and elected mayors according to proposer

\begin{tabular}{|r|c|c|c|c|}
\hline predlagatelj & $\begin{array}{c}\text { število } \\
\text { kandidatov }\end{array}$ & delež (v \%) & $\begin{array}{c}\text { izvoljeni } \\
\text { župani }\end{array}$ & delež (v \%) \\
\hline parlamentarne stranke & $\mathbf{5 2 8}$ & $\mathbf{6 2 , 3}$ & $\mathbf{1 1 6}$ & $\mathbf{5 5 , 2}$ \\
\hline$S D S$ & 120 & 14,2 & 27 & 12,9 \\
\hline$S D S$ & 101 & 11,9 & 48 & 22,9 \\
\hline$L D S$ & 94 & 11,1 & 13 & 6,2 \\
\hline$N S I$ & 83 & 11,0 & 17 & 8,1 \\
\hline$S N S$ & 21 & 9,4 & 9 & 4,3 \\
\hline DeSUS & 19 & 2,5 & 2 & 1,0 \\
\hline neparlamentarne stranke & $\mathbf{1 0 6}$ & $\mathbf{1 2 , 5}$ & $\mathbf{5}$ & 0,0 \\
\hline koalicije strank & $\mathbf{4 3}$ & $\mathbf{5 , 1}$ & $\mathbf{2 0}$ & $\mathbf{9 , 5}$ \\
\hline nestrankarski kandidati & $\mathbf{1 7 0}$ & $\mathbf{2 0 , 1}$ & $\mathbf{6 9}$ & $\mathbf{3 2 , 9}$ \\
\hline skupaj & $\mathbf{8 4 7}$ & $\mathbf{1 0 0 , 0}$ & $\mathbf{2 1 0}$ & $\mathbf{1 0 0 , 0}$ \\
\hline
\end{tabular}

Nestrankarski kandidati so predstavljali slabo petino vseh kandidatov. Sto sedemdeset nestrankarskih kandidatov je kandidiralo v 126 občinah (60\% vseh občin v Sloveniji). Največ, in sicer štirje, so kandidirali v občinah Piran, Makole in Kostanjevica na Krki. V 84 občinah so kandidirali le strankarski kandidati, v 10 pa samo nestrankarski (glej karto 1). 
Karta 1: Število nestrankarskih kandidatov v posameznih občinah na lokalnih volitvah 2006 Map 1: Number of nonparty candidates for mayors on local election 2006 by municipalities

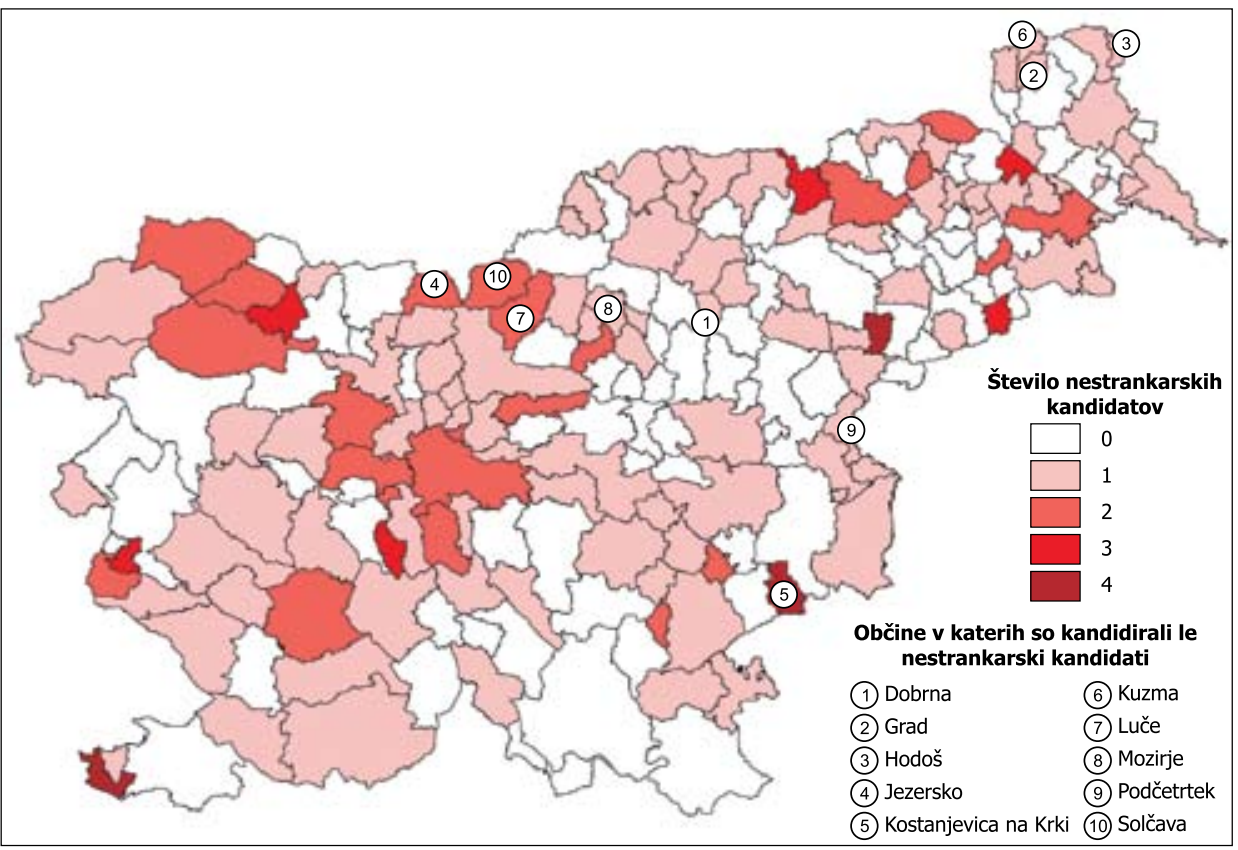

V Sloveniji obstajajo opazne regionalne razlike glede števila nestrankarskih kandidatov (glej karto 2 in tabelo 3; Pri interpretaciji rezultatov po statističnih regijah se je treba zavedati, da na izračunane deleže močno vpliva majhno število občin v regiji, kar še posebno velja za Zasavsko, Posavsko, Obalno-kraško in Notranjsko-kraško regijo.). Najbolj izstopa Zasavska regija, saj niti v eni občini ni kandidiral nestrankarski kandidat. Podpovprečna zastopanost je značilna tudi za Savinjsko in Podravsko statistično regijo kjer so bili nestrankarski kandidati prisotni v manj kot polovici občin. Podobno je tudi v statistični regiji Jugovzhodna Slovenija, kjer so volivci v polovici občin lahko izbrali tudi nestrankarskega kandidata. Na drugi strani izstopa Osrednjeslovenska statistična regija, kjer so bili nestrankarski kandidati prisotni kar v 80,8\% občinah. Malo manjši delež (75\%) imata Koroška in Posavska regija. Zelo zanimiva situacija je v Savinjski regiji, kjer imamo v Zgornjesavinjski dolini in Posotelju močno prisotnost nestrankarskih kandidatov, $v$ osrednjem delu pa so kandidirali le v občinah Laško, Slovenske Konjice, Dobrna in Vitanje.

Nasprotno pa ni pomembnejših razlik povezanosti med velikostjo občine in zastopanostjo nestrankarskih kandidatov. V vseh štirih razredih (delitev v razrede je predstavljena $\mathrm{v}$ tabeli 1) so bili nestrankarski kandidati prisotni v okoli $60 \%$ občin. Takšno stanje lahko pripišemo liberalnejši zakonodaji, oziroma prej omenjeni odločbi Ustavnega sodišča o delni razveljavitvi 68. člena Zakona o lokalnih volitvah. Saj je število podpisov za vložitev kandidature sedaj neodvisno od velikosti občine. 
Tabela 3: Regionalne razlike v zastopanosti nestrankarskih kandidatov na lokalnih volitvah 2006 Table 3: Regional differences in participation of nonparty candidates on local elections 2006

\begin{tabular}{|l|r|r|r|r|}
\hline & skupaj & $\begin{array}{c}\text { občine brez } \\
\text { nestrankarskim } \\
\text { kandidatom }\end{array}$ & $\begin{array}{c}\text { občine z } \\
\text { nestrankarskim } \\
\text { kandidatom }\end{array}$ & $\begin{array}{c}\text { delež občine z } \\
\text { nestrankarskim } \\
\text { kandidatom }\end{array}$ \\
\hline Zasavska & 3 & 3 & 0 & 0,0 \\
\hline Savinjska & 33 & 17 & 16 & 48,5 \\
\hline Podravska & 41 & 21 & 20 & 48,8 \\
\hline JV Slovenija & 20 & 10 & 10 & 50,0 \\
\hline Gorenjska & 18 & 7 & 11 & 61,1 \\
\hline Notranjsko-kraška & 6 & 2 & 4 & 66,7 \\
\hline Pomurska & 27 & 9 & 18 & 66,7 \\
\hline Goriška & 13 & 4 & 9 & 69,2 \\
\hline Obalno-kraška & 7 & 2 & 3 & 71,4 \\
\hline Posavska & 4 & 1 & 9 & 75,0 \\
\hline Koroška & 12 & 3 & 21 & 75,0 \\
\hline Osrednjeslovenska & 26 & $\mathbf{1 2 6}$ & 80,8 \\
\hline SKUPAJ & $\mathbf{2 1 0}$ & $\mathbf{8 4}$ & $\mathbf{6 0 , 0}$ \\
\hline
\end{tabular}

Zanimivo je, da so nestrankarski kandidati, kandidirali le v petih od enajstih mestnih občin. Po dva v Ljubljani in Mariboru, ter po eden v Kranju, Novem mestu in Slovenj Gradcu. $\mathrm{V}$ drugih mestnih občinah so se za župansko mesto potegovali le strankarski kandidati. Omenjeno dejstvo si lahko razlagamo na eni strani s problemom organiziranja učinkovite predvolilne kampanje $\mathrm{v}$ večjih skupnostih, na drugi pa $\mathrm{z}$ večjo prisotnostjo kandidatov neparlamentarnih strank v mestnih okoljih. Od 86 kandidatov za župane mestnih občin so jih kar 35 (40,7\%) predlagale neparlamentarne stranke, kar je neprimerno več od državnega povprečje (glej tabelo 2).

$\mathrm{Na}$ koncu pregleda kandidature je treba poudariti še eno skupino občin, ki glede števila nestrankarskih kandidatov še posebno odstopa od državnega povprečja, in sicer t.i. "nove občine". V to skupino uvrščamo sedemnajst občin, ki so nastale leta 2006. Zanje velja nadpovprečno visoka zastopanost nestrankarskih kandidatov na županskih volitvah. Slednji so predstavljali 41\% vseh kandidatov v omenjenih občinah (za državno povprečje glej tabelo 2), prisotni pa so bili v vseh občinah razen Sveti Tomaž.

\section{Rezultati županskih volitev}

Pred natančnejšo analizo uspešnosti nestrankarskih kandidatov so predstavljene nekatere splošne značilnosti rezultatov županskih volitev. Izmed 210 županov, jih je bilo 138 $(65,7 \%)$ izvoljenih v prvem, preostalih $72(34,3 \%)$ pa v drugem krogu volitev. Ponovno je bilo izvoljenih 128 (61\%) županov, v 65 občinah (31\%) je župansko mesto zasedel nov kandidat. V 17 občinah so župana volili prvič. 
Sto šestnajst $(55,2)$ novih županov prihaja iz vrst parlamentarnih stranke, 69 (32,9\%) je nestrankarskih kandidatov, 20 županov je koalicijskih kandidatov, le 5 novih županov pa so predlagale neparlamentarne stranke (glej tabelo 2 in karto 3). Med strankami je bila najuspešnejša SLS - Slovenska ljudska stranka z 48 župani (poleg tega je sodelovala pri kandidaturi osmih izvoljenih koalicijski kandidatov), sledi ji SDS - Slovenska demokratska stranka (27 županov +7 koalicijskih županov) ter LDS - Liberalna demokracija Slovenije (17 županov +7 koalicijskih županov). Demokratična stranka upokojencev (DeSUS) je edina parlamentarna stranka brez samostojnega župana, je pa sodelovala pri kandidaturi štirih izvoljenih koalicijskih kandidatov.

Kandidati neparlamentarnih strank niso bili uspešni, saj jim je pripadlo le pet županskih stolčkov. Regionalno gledano izstopajo tri obalne občine. V Kopru je zmagal Boris Popovič (Koper je naš), v Izoli Tomislav Klokočovnik (Izola je naša) in v Piranu Tomaž Gantar (Piran je naš). Preostali dve občini z županom iz vrst neparlamentarnih strank sta Preddvor in Ajdovščna. Poudariti je treba, da omenjene neparlamentarne stranke z izjemo Narodne stranke dela, ki je kandidirala Marjana Poljšaka v Ajdovščini, delujejo le na območju ene občine in so tako po načinu delovanja bliže nestrankarskim listam kot pa političnim strankam.

Tabela 4: Rezultati lokalnih volitev 2006 in 2002

Table 4: Results of local election 2006 and 2002.

\begin{tabular}{|l|r|r|r|r|}
\hline & $\begin{array}{c}\text { število } \\
\text { županov } \\
\mathbf{2 0 0 6}\end{array}$ & $\begin{array}{c}\text { delež } \\
(\mathbf{v} \%)\end{array}$ & $\begin{array}{c}\text { število } \\
\text { županov } \\
\mathbf{2 0 0 2}\end{array}$ & $\begin{array}{c}\text { delež } \\
(\mathbf{v} \%)\end{array}$ \\
\hline parlamentarna stranka & 116 & 55,2 & 107 & 55,4 \\
\hline neparlamentarna stranka & 5 & 2,4 & 2 & 1,0 \\
\hline koalicija strank & 20 & 9,5 & 25 & 13,0 \\
\hline nestrankarski kandidat & 69 & 32,9 & 59 & 30,6 \\
\hline skupaj & 210 & 100,0 & 193 & 100,0 \\
\hline
\end{tabular}

V nasprotju s kandidati neparlamentarnih strank so bili nestrankarski kandidati zelo uspešni. Kljub temu, da so pomenili le petino vseh županskih kandidatov, so zasedli kar 69 oziroma tretjino županskih mest. Osemintrideset nestrankarskih županov je bilo ponovno izvoljenih, 31 jih je položaj zasedlo prvič. Kljub velikemu deležu nestrankarskih županov pa vseeno ne moremo trditi, da so lokalne volitve 2006 prelomne. Primerjava $\mathrm{z}$ lokalnimi volitvami 2002 sicer pokaže, da se je število nestrankarskih županov povečalo za deset, vendar pa je njihov delež, zaradi večjega števila občin, ostal približno enak (glej tabelo 4). Iz tega lahko sklepamo, da je - če gledamo Slovenijo kot celoto - trditev o velikem uspehu nestrankarskih kandidatov oziroma izgubi moči političnih strank prenagljena. Politične stranke imajo v rokah še vedno več kot dve tretjini vseh županskih mest, od tega jih večina odpade na parlamentarne stranke oziroma koalicije parlamentarnih strank (glej tabelo 4). 
Karta 2: Novoizvoljeni župani glede na predlagatelja kandidature

Map 2: Newly elected majors according to proposer

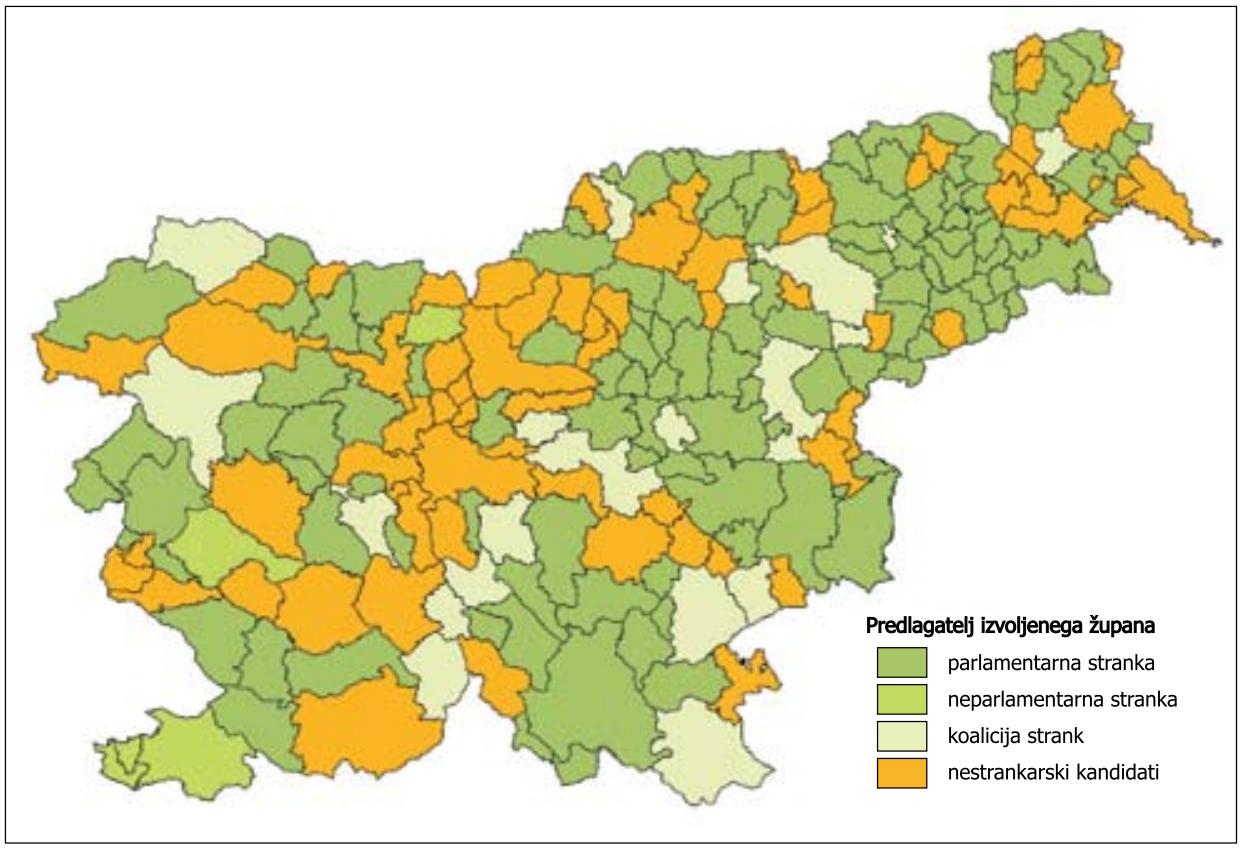

Slika je malo drugačna, če si pogledamo položaj po posameznih statističnih regijah (glej tabelo 5). V treh regijah, Osrednjeslovenski, Notranjsko-kraški in Pomurski, delež nestrankarskih županov občutno presega državno povprečje. Izstopa predvsem prva, kjer so bili nestrankarski župani izvoljeni v več kot polovici vseh občin. Izredno pomembno je tudi, da Ljubljano kot največjo in najpomembnejšo občino v državi vodi nestrankarski župan. Nasprotno je delež nestrankarskih županov v Zasavski, Obalno-kraški in Podravski regiji daleč od državnega povprečja. Posebnost je Zasavka regija, kjer nestrankarski kandidati sploh niso kandidirali.

Primerjava lokalnih volitev 2006 in 2002 (glej tabelo 5) pokaže, da je v štirih regijah - Notranjsko-kraški (3 nestrankarski župani), Koroški (4), Podravski (7) in Zasavski (0) število nestrankarskih županov ostalo nespremenjeno. Kljub temu je v Podravski regiji zaradi večjega števila občin prišlo do zmanjšanja njihovega relativnega deleža (za 3,5 odstotne točke). V petih regijah se je povečalo število nestrankarskih županov (Osrednjeslovenska, Pomurska, Goriška, JV Slovenija ter Posavska). Izstopa predvsem JV Slovenija, kjer se je njihovo število povečalo za štiri oziroma 23,7 odstotne točke. Zmanjšanje nestrankarskih kandidatov beležimo v treh regijah - Obalno-kraški, Savinjski in Gorenjski. V prvi sta bila izvoljena dva nestrankarska kandidata manj, v drugih dveh pa eden. Dejansko je bil v Obalnokraški regiji izvoljen le en nestrankarski župan manj, saj je Boris Popovič ponovno izvoljeni župan Kopra, na volitvah 2002 kandidiral kot nestrankarski kandidat, na zadnjih volitvah pa 
kot kandidat neparlamentarne stranke Koper je naš. V Savinjski regiji je treba omeniti občine v Zgornjesavinjski dolini, saj so bili v vseh izvoljeni nestrankarski župani.

Tabela 5: Rezultati nestrankarskih kandidatov na lokalnih volitvah 2002 in 2006.

Table 5: Nonparty candidates results on local elections 2002 and 2006.

\begin{tabular}{|c|c|c|c|c|c|}
\hline & \multicolumn{2}{|c|}{ Volitve 2002} & \multicolumn{2}{|c|}{ Volitve 2006} & \multirow{2}{*}{$\begin{array}{c}\text { sprememba } \\
\text { deleža } \\
2002-2006\end{array}$} \\
\hline & $\begin{array}{c}\text { nestrankarski } \\
\text { župani }\end{array}$ & delež & $\begin{array}{c}\text { nestrankarski } \\
\text { župani }\end{array}$ & delež & \\
\hline Osrednjeslovenska & 11 & 44,0 & 14 & 53,8 & $+9,8$ \\
\hline Notranjsko-kraška & 3 & 50,0 & 3 & 50,0 & 0,0 \\
\hline Pomurska & 10 & 38,5 & 13 & 48,1 & $+9,6$ \\
\hline Goriška & 3 & 25,0 & 5 & 38,5 & $+13,5$ \\
\hline Gorenjska & 7 & 41,2 & 6 & 33,3 & $-7,9$ \\
\hline Koroška & 4 & 33,3 & 4 & 33,3 & 0,0 \\
\hline JV Slovenija & 1 & 6,3 & 6 & 30,0 & $+23,7$ \\
\hline Savinjska & 10 & 31,3 & 9 & 27,3 & $-4,0$ \\
\hline Posavska & 0 & 0,0 & 1 & 25,0 & $+25,0$ \\
\hline Podravska & 7 & 20,6 & 7 & 17,1 & $-3,5$ \\
\hline Obalno-kraška & 3 & 42,9 & 1 & 14,3 & $-28,6$ \\
\hline Zasavska & 0 & 0,0 & 0 & 0,0 & 0,0 \\
\hline Slovenija & 59 & 30,6 & 69 & 32,9 & 2,3 \\
\hline
\end{tabular}

Na uspešnost nestrankarskih kandidatov delno vpliva tudi velikost občin. Delež nestrankarskih županov je največji v občinah z do 2000 prebivalcev (od 25 občin jih ima 10 oziroma $40 \%$ nestrankarske župane). $Z$ večanjem števila prebivalcev se delež nestrankarskih županov manjša. V občinah, ki imajo od 2000 do 5000 prebivalcev, je njihov delež $37,1 \%$ (od 89 občin jih ima 33 nestrankarske župane), v občinah od 5000 do 10000 prebivalcev se njihov delež spusti na 28,9\% (od 45 občin jih ima 13 nestrankarske župane). Najmanjši delež 25,5\% imajo občine z več kot 10000 prebivalci (od 51 občin jih ima 13 nestrankarske župane).

Nestrankarski kandidati so bili uspešni v treh od enajstih mestnih občin - Ljubljana, Kranj in Slovenj Gradec. V nemestnih občinah je bila njihova uspešnost skladna z državnim povprečjem.

Enako kot pri analizi kandidatur je tudi pri volilnih rezultatih treba izpostaviti t.i. »nove občine«, ki glede uspešnosti nestrankarskih kandidatov močno izstopajo iz državnega povprečja, saj so bili slednji izvoljeni kar v 10 od 17 občin $(58,8 \%)$. Med razlogi za takšno stanje bi izpostavili dva. Prvič, zaradi »mladosti« občin, strankam še ni uspelo oblikovati lokalnih strankarskih struktur. Drugič, za nastanek novih občin so večinoma zaslužne nestrankarske lokalne civilne iniciative. Le-te so na volitvah kandidirale svoje kandidate. Gledano z vidika rezultatov županskih volitev bi lahko dejali, da so si politične stranke (še posebno parlamentarne) z ustanavljanjem novih občin naredile medvedjo uslugo, saj je njihov vpliv v novih občinah omejen. 


\section{VOLITVE V OBČINSKE/MESTNE SVETE}

Poleg županov se na lokalnih volitvah volijo tudi člani občinskih svetov - občinski svetniki. Občinski svet je najvišji organ odločanja v občini (Zakon o lokalni samoupravi, 1993). Glede na velikost občine lahko občinski svet šteje od 7 do 45 članov. V občinah, katerih občinski svet šteje manj kot 12 članov, se svetniki volijo po sistemu relativne večine. V občinah, kjer občinski svet šteje 12 ali več članov, pa se svetniki volijo po proporcionalnem sistemu (D'Hondtov sistem). V Sloveniji potekajo lokalne volitve po proporcionalnem sistemu v 150 občinah, po večinskem pa v 60.

Zaradi enakopravnejše zastopanosti vseh delov občine v občinskem svetu so nekatere občine razdeljene na več volilnih enot. Delitev na več volilnih enot vpliva tako na kandidiranje kot na volilne rezultate. Posebnost kandidiranja v občinah razdeljenih na več volilnih enot, je v tem, da kandidatom ni treba kandidirati v vseh volilnih enotah, kandidaturo pa je treba vložiti v vsaki volilni enoti posebej. Slednje je pomembno predvsem za nestrankarske kandidate, ki morajo - če želijo kandidirati $v$ vseh volilnih enotah - v vsaki volilni enoti zbrati predpisano število podpisov volivcev.

V občinah, ki so razdeljene na več volilnih enot in imajo proporcionalni volilni sistem, se mandati delijo na dveh ravneh. Najprej na ravni volilnih enot, ostanek mandatov pa na občinski ravni. Pri tem lahko pri delitvi mandatov na občinski ravni sodelujejo le liste, ki so kandidirale $\mathrm{v}$ dveh ali več volilnih enotah. Zato imajo liste, ki kandidirajo le v eni volilni enoti, manjše možnosti za pridobitev mandata. Omenjeno določilo največkrat prizadene nestrankarske liste, ki pogosto kandidirajo le v eni volilni enoti.

\section{Kandidiranje}

Na lokalnih volitvah 2006 se je za 3351 mest v občinskih svetih potegovalo 26.658 kandidatov. Parlamentarne stranke so kandidirale 16.641 oziroma $62,4 \%$ vseh kandidatov, neparlamentarne stranke $4.533(17 \%), 5.296(19,9 \%)$ kandidatov je bilo nestrankarskih in le $188(0,7 \%)$ kandidatov je bilo koalicijskih.

Nestrankarski kandidati lahko svojo kandidaturo vložijo na dva načina, in sicer prek nestrankarske liste ali pa samostojno. $V$ prvem primeru skupina najmanj petnajstih volivcev oblikuje listo kandidatov, le-ta pa oblikuje svojo listo kandidatov. Pri samostojni kandidaturi mora vsak kandidat posebej zbrati podpise najmanj petnajstih volivcev. Prva oblika kandidiranja je značilna predvsem za občine s proporcionalnim volilnim sistemom, druga pa večinoma $\mathrm{v}$ občinah $\mathrm{z}$ večinskim prebivalstvom. Največ nestrankarskih list je kandidiralo $\mathrm{v}$ Mariboru (20), Lendavi (10), Novi Gorici (10) in Postojni (10).

Solčava je edina občina, v kateri ni kandidiral niti en kandidat parlamentarnih strank. $\mathrm{V}$ vseh drugih občinah so parlamentarne stranke kandidirale vsaj enega kandidata. V največ občinah je svoje kandidate kandidirala SDS, in sicer v 202 (v 199 samostojno, v 3 koalicijsko), sledi ji SLS s 197 občinami (194 samostojno, 3 koalicijsko) in LDS s 188 občinam (vse samostojno). Med parlamentarnimi strankami izstopa SNS, ki je svoje kandidate kandidirala le v 72 občinah. Neparlamentarne stranke so bile prisotne v 143 občinah (v največ občinah so kandidirale Stranka mladih Slovenije, Aktivna Slovenija in Zeleni). 
Nestrankarski kandidati so kandidirali v 186 občinah (88,6\% vseh občin) (glej karto 3). Podobno kot pri kandidiranju nestrankarskih kandidatov za župane tudi pri kandidatih za člane občinskih svetov obstajajo pomembne regionalne razlike. Nestrankarski kandidati so podpovprečno zastopani v Podravski (le v 80,5\% občin), Savinjski $(81,8 \%$ ) in Pomurski $(85,2 \%)$ statistični regiji. Nasprotno so bili v Osrednjeslovenski, Obalno-kraški in Posavski regiji nestrankarski kandidati prisotni v vseh občinah. V vseh ostalih regijah imamo po eno občino kjer ni bilo nestrankarskih kandidatov na volitvah v občinski svet.

Velikost občin ni bistveno vplivali na kandidiranje nestrankarskih kandidatov. Delno izstopajo le največje občine (nad 10.000 prebivalcev), kjer so nestrankarski kandidati kandidirali v 48 od 51 občin $(94,1 \%)$. Prav tako ni večjih razlik med različnimi volilnimi sistemi. Tako v občinah z večinskim kot proporcionalnim sistemom so bili nestrankarski kandidati prisotni v $88 \%$ občin. Nestrankarske liste so bile prisotne v vseh mestnih občinah in v $87,9 \%$ nemestnih. Ponovno je treba poudariti nove občine, kjer so bili nestrankarski kandidati prisotni v 16 od 17 občin $(94,1 \%)$.

\section{Rezultati volitev v občinske svete}

Od 3351 mest v občinskih svetih jih je 2535 oziroma 75,6\% pripadlo kandidatom parlamentarnih strank (glej tabelo 6). Sledijo jim nestrankarski kandidati, ki so zasedli 600 mest (17,9\%), kandidati neparlamentarnih strank so zasedli 196 mest (5,8\%), le 23 mest (0,7\%) pa je pripadlo koalicijskim kandidatom. Med parlamentarnimi strankami je bila najuspešnejša SDS, saj so njeni kandidati zasedli več kot petino mest v občinskih svetih. Sledijo ji LDS, SLS in SD. SNS je bila med parlamentarnimi strankami najmanj uspešna, vendar je njen neuspeh povezan z majhnim številom občin, v katerih je kandidirala. Parlamentarne stranke so bile uspešnejše v občinah s proporcionalnim volilnim sistemom, kjer so zasedle 78,3\% mandatov v občinskih svetih. V občinah z večinskim sistemom je bil njihov delež malo nad $60 \%$.

Šesto nestrankarskih svetnikov je zastopanih v 150 slovenskih občinah, kar pomeni $71,4 \%$ vseh občin. V 60 občinah ni niti enega nestrankarskega svetnika. Nestrankarski svetniki so bili uspešnejši v občinah z večinskim volilnim sistemom, kjer so dobili kar 33,6\% vseh mandatov, v nasprotju z občinami s proporcionalnim sistemom, kjer so dobili le 14,9\% mandatov. Omenjena razlika je na eni strani, posledica različnega načina glasovanja. Večinski volilni sistem je bolj personaliziran, saj volivci glasujejo za natančno določenega kandidata, ne pa za neko listo kandidatov. Na drugi strani pa na uspešnost nestrankarskih kandidatov vpliva tudi velikost občin. V manjših občinah - v katerih se voli po večinskem sistemu -, je lažje organizirati volilno kampanjo, prepoznavnost kandidatov ter s tem njihova možnost za izvolitev veliko večja kot v večjih.

Regionalno gledano obstajajo velike razlike v zastopanosti nestrankarskih svetnikov v občinskih svetih (glej tabelo 7). Situacija je zelo podobna tisti pri županskih volitvah. Najbolj izstopajo občine v Zasavski regiji, kjer ni niti enega nestrankarskega svetnika. Močno pod državnem povprečjem sta tudi Podravska regija, kjer so prisotni le v dobri polovici občin, in Savinjska regija, kjer so prisotni v slabih dveh tretjinah občin. Z nadpovprečnim deležem se ponaša predvsem Osrednjeslovenska regija. 
Tabela 6: Število in delež kandidatov za občinske svete glede na predlagatelja Table 6: Number and share of council candidates according to proposer

\begin{tabular}{|c|c|c|r|r|}
\hline & \multicolumn{2}{|c|}{ volitve 2006 } & \multicolumn{2}{c|}{ volitve 2002 } \\
\hline predlagatelj & št. občin & \% & \multicolumn{1}{c|}{ št. občin } & \multicolumn{1}{c|}{ \% } \\
\hline parlamentarne stranke & 2532 & 75,6 & $\begin{array}{r}2603 \\
(2483)\end{array}$ & $\begin{array}{r}81,2 \\
(77,5)\end{array}$ \\
\hline SDS & 682 & 20,4 & 444 & 13,9 \\
\hline LDS & 559 & 16,7 & 795 & 24,8 \\
\hline SLS & 473 & 14,1 & 485 & 15,1 \\
\hline SD & 386 & 11,5 & 282 & 8,8 \\
\hline NSi & 227 & 6,8 & 285 & 8,9 \\
\hline DeSUS & 154 & 4,6 & 150 & 4,7 \\
\hline SNS & 51 & 1,5 & 42 & 1,3 \\
\hline neparlamentarne stranke & 196 & 5,8 & $80(200)$ & $2,5(6,2)$ \\
\hline koalicija strank & 23 & 0,7 & 17 & 0,5 \\
\hline nestrankarski kandidati & 600 & 17,9 & 505 & 15,8 \\
\hline skupaj & 3351 & 100 & 3205 & 100 \\
\hline
\end{tabular}

V primerjavi z volitvami 2002 (glej tabelo 7) se je število nestrankarskih svetnikov povečalo za 95 (s 505 na 600). Relativno gledano se je njihov delež povečal za 2,1 odstotne točke (s $15,8 \%$ na $17,9 \%$ ). Kljub rasti pa ne bi mogli govoriti o revolucionarnih spremembah oziroma o zgodovinskem preobratu in zatonu strank. Delež občin z nestrankarskimi svetniki je ostal tako rekoč nespremenjen. Leta 2002 je znašal 71\% (137 od 193 občin), štiri leta pozneje pa znaša 71,4\% (150 od 210 občin).

Rast števila nestrankarskih svetnikov beležijo vse statistične regije razen Pomurske in Obalno-kraške. Medtem, ko je v prvi prišlo do manjšega upada (s 57 na 53 svetnikov), je bil v drugi upad veliko večji (s 33 na 19 svetnikov). Vzrok zanj je oblikovanje treh lokalnih strank Koper je naš, Izola je naša in Piran je naš, v katere se je včlanil del nestrankarskih svetnikov, poleg tega pa so omenjene stranke v vseh treh obalnih občinah dosegle dober volilni rezultat. Največjo rast nestrankarskih svetnikov dosega Osrednjeslovenska regija. Ta je v prvi vrsti posledica uspeha Liste Zorana Jankovića v Ljubljani in nekaterih nestrankarskih list v sosednjih občinah (Ig, Vodice, Trzin, Dol,...). Omenjen porast - iz 83 na 135 nestrankarskih svetnikov - je verjetno pripeljala do teze o zmanjšanju vloge in moči političnih strank, ki je nastala po zadnjih lokalnih volitvah.

Tezi o velikih spremembah nasprotuje tudi primerjava deležev nestrankarskih svetnikov v občinskih svetih po volitvah 2006 in 2002 . V 56 občinah $(26,7 \%)$ je delež ostal enak, v 67 $(31,9 \%)$ je prišlo do padca, v $70(33,3 \%)$ pa do rasti njihovega deleža (17 občin je novih). Najbolj je delež upadel v Kopru (za 37,9 odstotne točke), Dobrovniku (za 30,6 odstotne točke) in Selnici ob Dravi (za 26,7 odstotne točke). Najbolj pa je narasel v Podlehniku (za 57,1 odstotne točke), Ljubljani (za 42,2 odstotne točke), Log-Dragomeru (za 37,7 odstotne točke), Dornavi (za 36,4 odstotne točke) in Mozirju (za 30,8 odstotne točke). Če pogledamo položaj na ravni statističnih regij, izstopata predvsem dve regiji Osrednjeslovenska in Podravska. V 
prvi se je, kar v 16 občinah (64\% vseh občin v regiji) povečal delež nestrankarskih svetnikov. Nasprotno se je zgodilo v Podravski regiji, kjer je v 15 občinah (42,9\% vseh občin v regiji) njihov delež upadel. V ostalih regijah je bilo razmerje med številom občin, kjer je delež upadel, in tistimi, $\mathrm{v}$ katerih je narasel, približno enako.

Tabela 7: Rezultati lokalnih volitev 2002 in 2006

Table 7: Results of local elections 2002 and 2006

\begin{tabular}{|c|c|c|c|c|c|c|c|}
\hline \multirow[b]{2}{*}{ 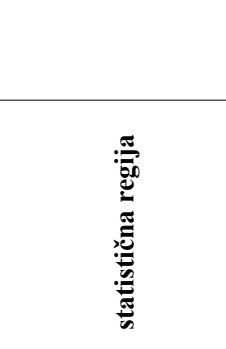 } & \multicolumn{3}{|c|}{ volitve 2002} & \multicolumn{3}{|c|}{ volitve 2006} & \multirow{2}{*}{ 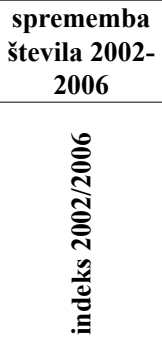 } \\
\hline & 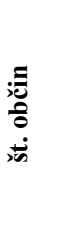 & 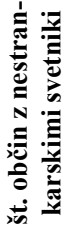 & 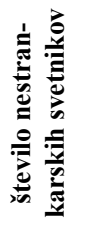 & 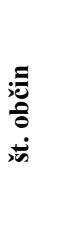 & 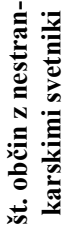 & 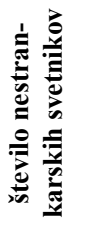 & \\
\hline Zasavska & 3 & 0 & 0 & 3 & 0 & 0 & - \\
\hline Obalno-kraška & 7 & 7 & 33 & 7 & 6 & 19 & 58 \\
\hline Pomurska & 26 & 17 & 57 & 27 & 21 & 53 & 93 \\
\hline Notranjsko-kraška & 6 & 5 & 29 & 6 & 5 & 30 & 103 \\
\hline Podravska & 35 & 23 & 71 & 41 & 23 & 75 & 106 \\
\hline Posavska & 3 & 3 & 12 & 4 & 3 & 13 & 108 \\
\hline Koroška & 11 & 9 & 25 & 12 & 10 & 28 & 112 \\
\hline Goriška & 12 & 9 & 28 & 13 & 9 & 32 & 114 \\
\hline Gorenjska & 17 & 12 & 65 & 18 & 13 & 75 & 115 \\
\hline Savinjska & 32 & 19 & 62 & 33 & 21 & 76 & 123 \\
\hline JV Slovenija & 16 & 11 & 40 & 20 & 16 & 64 & 160 \\
\hline Osrednjeslovenska & 25 & 22 & 83 & 26 & 23 & 135 & 163 \\
\hline Slovenija & 193 & 137 & 505 & 210 & 150 & 600 & 119 \\
\hline
\end{tabular}

Da bi ugotovili, kakšen vpliv imajo nestrankarski svetniki na sprejemanje odločitev v občinskih svetih smo občine razdelili v pet razredov glede na njihov delež v občinskih svetih (glej karto 3).

V prvem so tiste brez nestrankarskih svetnikov. Za občine uvrščene vanj je značilna velika heterogenost. V njem najdemo tako velike (npr. Velenje, Koper, Trbovlje, Slovenska Bistrica), kot male občine (npr. Osilnica, Dobje, Kobilje), mestne in nemestne občine, občine $\mathrm{z}$ večinskim in proporcionalnim sistemom.

$\mathrm{V}$ drugem so tiste, $\mathrm{v}$ katerih imajo nestrankarski svetniki do $10 \%$ mandatov, zato nimajo večjega vpliva na odločanje. $V$ njem so občine s proporcionalnim sistemom, $z$ enim ali dvema nestrankarskima svetnikoma (npr. Moravče, Bovec, Piran, Brežice). 
$\mathrm{V}$ tretjem razredu so občine, ki imajo od $10 \%$ pa do manj kot $25 \%$ nestrankarskih svetnikov v občinskem svetu. Tudi v teh občinah je vpliv nestrankarskih svetnikov majhen. V grobem bi lahko občine v tem razredu razdelili v tri skupine. Prvo sestavljajo občine z večinskim sistemom, ki imajo enega oziroma dva nestrankarska svetnika (primeri: Žetale, Sodražica, Odranci), drugo manjše občine s proporcionalnim sistemom $\mathrm{z}$ dvema nestrankarskima svetnikoma (primeri: Brezovica, Poljčane, Lovrenc na Pohorju), tretjo pa večje občine s proporcionalnim sistemom, ki imajo tri ali več nestrankarskih svetnikov (primeri: Maribor, Kamnik, Domžale).

V četrtem razredu so občine s 25 do manj kot 50\% nestrankarskih svetnikov. V slednjih imajo nestrankarski svetniki že zelo pomemben vpliv na odločanje, vendar ni nujno, da so najmočnejša skupino v občinskem svetu. Njihov vpliv je manjši, če mandati pripadajo različnim listam. Tudi v tem razredu najdemo med seboj zelo različne občine, nekatere so manjše z večinskim volilnim sistemom (primeri: Bloke, Razkrižje, Ljubno), spet druge so večje s proporcionalnim volilnim sistemom (primeri: Dolenjske Toplice, Komenda, Šoštanj, Nova Gorica).

$\mathrm{V}$ zadnjem, petem razredu so občine, kjer nestrankarski svetniki zasedajo $50 \%$ in več sedežev v občinskem svetu. Izstopajo občine Hodoš, Jezersko, Podlehnik in Solčava - vse imajo večinski volilni sistem in zelo malo prebivalcev - v katerih je celotni občinski svet sestavljen iz nestrankarskih svetnikov. Absolutna večina nestrankarskih svetnikov v občinskem svetu slednjim omogoča popoln nadzor nad sprejemanjem odločitev. Vendar se je treba zavedati, da je delež v večini primerov razdeljen na več nestrankarskih list oziroma samostojnih nestrankarskih kandidatov ter da ti pogosto ne delujejo enotno. Le v šestih občinah - Ljubljani, Jezerskem, Svetem Andražu v Slovenskih goricah, Središču ob Dravi, Solčavi in Podlehniku - ima ena nestrankarska lista absolutno večino v občinskem svetu. Kot vidimo, gre z izjemo Ljubljane za manjše občine $\mathrm{z}$ večinskim volilnim sistemom. V tej luči je uspeh Liste Zorana Jankovića še toliko bolj izstopajoč.

Da bi ugotovili ali drži teza o velikih spremembah na slovenskem političnem prizorišču smo podrobneje analizirali spremembe $\mathrm{v}$ številu in deležih občin v posameznih razredih med lokalnimi volitvami 2002 in 2006 . V kolikor omenjena teza drži, potem bi pričakovali, da se je delež občin v zadnjih dveh razredih povečal, v prvem pa zmanjšal. Primerjava je pokazala, da je delež občin v prvem razredu ostal nespremenjen. Leta 2002 je bilo v tem razredu $29 \%$ občin, leta 2006 pa 28,6\%. Enako velja tudi za četrti razred, v katerem je bilo leta $200220,2 \%$ občin, leta 2006 pa $21 \%$. Zato pa je do občutnejše rasti prišlo v petem razredu, delež občin v tem razredu se je povečal s $7,2 \%$ na $12,9 \%$. Omenjena rast gre predvsem na račun novonastalih občin, saj je kar 7 od 17 »novih občin« v petem razredu.

$\mathrm{Na}$ splošno je značilno, da $\mathrm{v}$ zadnjem razredu prevladujejo majhne občine $\mathrm{z}$ manj kot 5000 prebivalci (takih je več kot $70 \%$ občin v tem razredu). Izmed 27 občin, ki se nahajajo v njem, imajo le tri več kot 10000 prebivalcev (Ljubljana, Log Dragomer in Postojna). Regionalno gledano jih je največ v Osrednjeslovenski regiji (Ljubljana z okolico), Gorenjski regiji, JV Sloveniji in v Zgornjesavinjski dolini (glej karto 3). Iz karte 3 je razvidno, da z izjemo Ljubljane in okoliških občin večina občin v petem razredu leži na perifernih območjih. Med mestnimi občinami imata le Ljubljana in Nova Gorica več kot $25 \%$ nestrankarskih svetnikov v občinskem svetu. Omenjene ugotovitve še dodatno potrjujejo že prej omenjeno trditev, da je 
teza o prelomnosti lokalnih volitev 2006 nastala pod vplivom volilnih rezultatov v Ljubljani in zanemarja rezultate v ostalih delih Slovenije.

Karta 3: Delež nestrankarskih svetnikov v občinskih svetih po lokalnih volitvah 2006 Map 3: Share of nonparty council members after local elections 2006

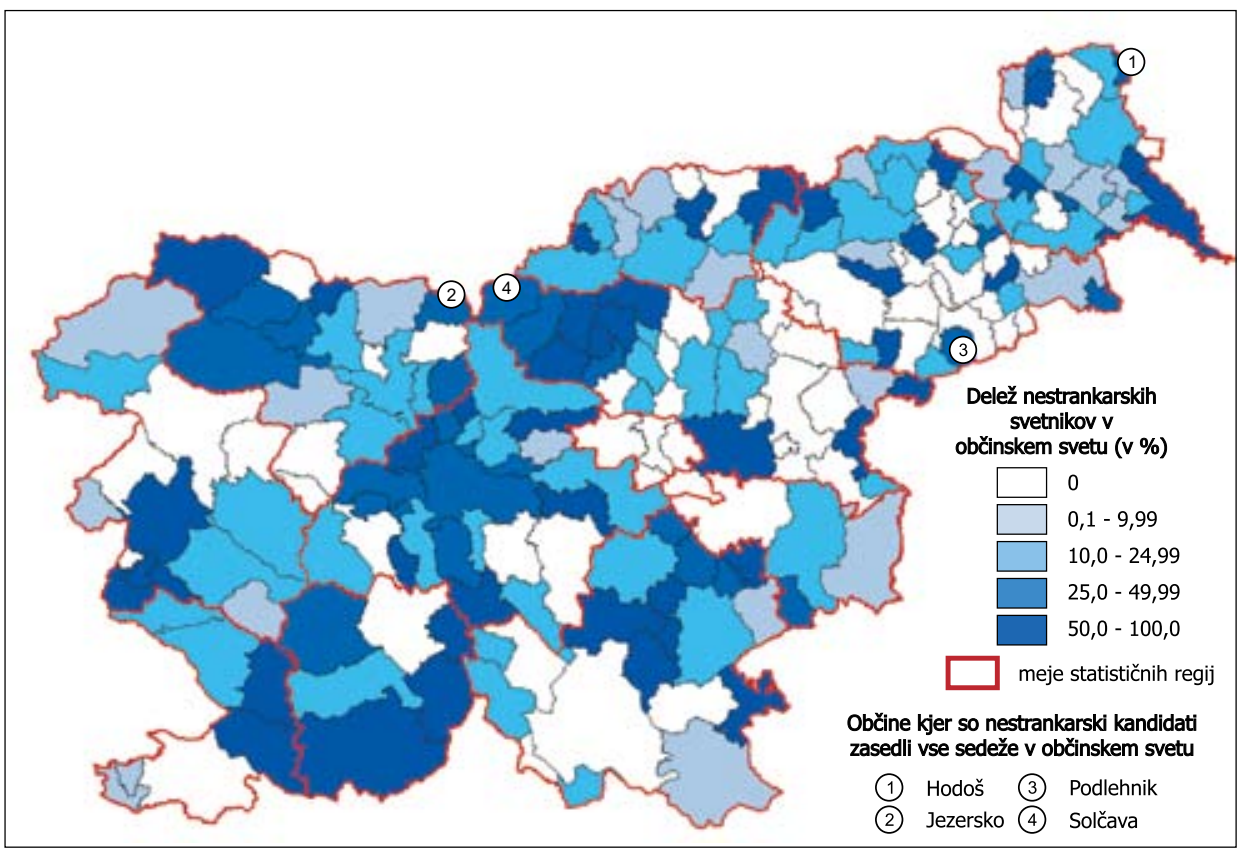

\section{ZAKLJUČEK}

Glavni namen pričujoče analize je bil preveriti tezo o velikem preobratu v slovenskem političnem prostoru na lokalnih volitvah 2006. V uvodu smo si postavili tri vprašanja: Ali smo bili dejansko priče pomembnemu preobratu v slovenskem političnem prostoru? Ali se lokalne volitve 2006 glede zastopanosti nestrankarskih list in županov bistveno razlikujejo od prejšnjih volitev? Ali obstajajo pomembne regionalne razlike med posameznimi predeli Slovenije glede zastopanosti nestrankarskih županov ter svetniških list?

Natančnejša analiza rezultatov lokalnih volitev 2006 je pokazala, da slednje niso bile tako prelomne, kot so prikazovali številni politični komentatorji. $\mathrm{Z}$ analizo smo zavrnili tezo o velikem uspehu nestrankarskih kandidatov oziroma pomembnem preobratu na slovenskem političnem prizorišču. Res je sicer, da imajo nestrankarski kandidati pomembno vlogo na lokalnem političnem prizorišču - zasedajo namreč 32,9\% županskih mest in 17,9\% mest v občinskih svetih -, vendar pa se njihov delež v primerjavi z lokalnimi volitvami 2002 ni bistveno spremenil. Če primerjamo njihove dosežke na lokalnih volitvah 1994, 1998, 2002 
in 2006 ugotovimo, da delež nestrankarskih županov in svetnikov narašča vse od leta 1994. Na prvih lokalnih volitvah leta 1994 je iz nestrankarskih vrst prišlo le 19,7\% županov in 9,4\% svetnikov (SURS, 2007). Ta delež se je leta 1998 povečal na $24,1 \%$ oziroma $11,7 \%$. Do najvišje rasti pa je prišlo na lokalnih volitvah 2002, ko je delež nestrankarskih svetnikov narasel na 17,1\%, delež nestrankarskih županov pa na 30,6\% (SURS, 2007). Tudi na zadnjih volitvah se je delež nestrankarskih svetnikov in županov povečal, vendar je bila rast občutno manjša kot na prejšnjih volitvah. Trditve o izredno močnem preboju neodvisnih kandidatov in o krizi strankarstva (Babič, 2006), so torej v nasprotju z dejanskimi rezultati.

Medtem ko za celotno državo velja, da se glede uspeha nestrankarskih kandidatov lokalne volitve 2006 bistveno ne razlikujejo od prejšnjih volitev, pa hkrati velja, da obstajajo pomembne regionalne razlike med posameznimi deli Slovenije. $Z$ analizo rezultatov na ravni statističnih regij smo ugotovili precejšnje razlike med regijami. Med dvanajstimi statističnimi regijami izstopa predvsem Osrednjeslovenska, kjer so nestrankarski kandidati zasedli kar 14 od 26 županskih mest in 135 od 481 svetniških mest. Regija dosega močno rast deleža nestrankarskih županov in občinskih svetnikov. Delež prvih se je povečal s $44 \%$ leta 2002 na $53,8 \%$, delež drugih pa s $17,6 \%$ leta 2002 na $28,1 \%$. Oba deleža sta močno nad državnim povprečjem, obenem pa je nadpovprečna tudi njuna rast.

Omenjena ugotovitev potrjuje dejstvo, da je teza o velikem uspehu nestrankarskih kandidatov nastala predvsem na podlagi volilnih rezultatov v Osrednjeslovenski regiji oziroma v Mestni občini Ljubljana. V manjši meri so nanjo vplivali tudi rezultati v treh obalnih občinah, kjer je glavna vloga pripadla neparlamentarnim strankam, ter rezultati v nekaterih mestnih občinah (predvsem Kranju, delno tudi v Mariboru).

Končna ugotovitev pričujoče analize je, da lokalne volitve 2006 z vidika uspeha nestrankarskih kandidatov niso prinesle pomembnejših sprememb v slovenski politični prostor. Res je, da so nestrankarski kandidati v nekaterih občinah dosegli zavidljiv uspeh, vendar pa bi bilo napačno, če bi rezultate v posameznih občinah posploševali na celotno državo.

\section{Viri in literatura}

Babič, M., 2006. Poljub smrti in pokvarjena zadrga. Sobotna priloga (Delo), 18. novembra 2006, str. 7.

Ministrstvo za notranje zadeve, 2006. Seznam političnih strank. URL: http://www.mnz.gov. si/si/splosno/vstopna_stran/za_drzavljane/dunz/politicne_stranke/(citirano 1. 10. 2006)

RVK (Republiška volilna komisija), 2007. Zgodovina volitev. URL: http://www.gov.si/rvk/ (citirano 15.1.2007)

Služba Vlade Republike Slovenije za lokalno samoupravo in regionalno politiko, 2006. Lokalne volitve 2006. URL: http://volitve.gov.si/lv2006/index.html (citirano 5. 2. 2007)

SURS (Statistični urad Republike Slovenije), 2007. Lokalne volitve 1994-2006, SURS, Ljubljana. URL: http://www.stat.si/doc/pub/06-RP-078-0701.pdf (citirano 1. 5. 2007)

SURS (Statistični urad Republike Slovenije), 2007. Volitve. URL: http://www.stat.si/tema splosno_volitve.asp (citirano 5. 2. 2007)

Zakon o lokalnih volitvah. URL: http://www.gov.si/rvk/LOKALNE_VOLITVE_2006/ ZLV. html (citirano 15. 4. 2007) 
Zakon o lokalni samoupravi. URL: http://www.gov.si/rvk/LOKALNE_VOLITVE_2006/ ZLS.html (citirano 15. 4. 2007)

\section{SUCCESS OF NONPARTY CANDIDATES ON LOCAL ELECTIONS 2006 IN SLOVENIA}

\section{Summary}

The Slovenian local election 2006 delivered some surprising results. According to many political commentators these elections represented an important milestone. The main reason for such statements was supposed to be the great success of non-party candidates. Ljubljana is mentioned by many as an example of great power of nonparty candidates and of the decline of traditional political parties. In Ljubljana Zoran Janković, a nonparty candidate, managed to win the election for mayor in the first round (he managed to win astonishing $62,99 \%$ of the votes). Besides, his non-party list managed to win the majority of seats (23 out of 45) in the municipality council.

Since no other examples were mentioned, it seemed that the thesis of the "great nonparty candidate success" was built on the Ljubljana election results. This led us to a more detailed analysis of the local election results. We were especially interested in the results of non-party candidates. Three questions were put into the center of our analysis: How successful were non-party candidates at the Slovenian local elections 2006? Did the 2006 local elections differ from the previous elections in 2002? Were there any regional differences in the success of non-party candidates?

The analysis is divided into three parts. In the first part some methodological problems are discussed. In the second part the success of non-party candidates on municipality mayor elections is analyzed and in the third part the success of non-party candidates at municipality council elections is analyzed. The data for the analysis were acquired from the internet site of Local elections 2006 (http://volitve.gov.si/lv2006/index.html) and the internet site of the Statistical Office of the Republic of Slovenia (http://www.stat.si/).

The analysis showed that the local elections 2006 were not as important as some commentators were suggesting. It is true that non-party candidates represent an important political force since they occupy $32,9 \%$ of mayor seats and $17,9 \%$ of the seats in municipality councils, but their share is not much bigger than it was after the 2002 local elections $(30,6 \%$ and $17,1 \%$ ). If the last election is compared with the three previous ones (in 1994, 1998 and 2002), it can be seen that the share of non-party candidates is constantly on the increase. In 1994 only $19,7 \%$ of mayor offices and 9,4 council seats were won by non-party candidates. Both shares rose in 1998 (to $24,1 \%$ and $11,7 \%$ ). The biggest growth happened at the 2002 election when non-party candidates managed to win $30,6 \%$ of mayor seats and $17,1 \%$ of municipality council seats (an increase of more than 6 percentage points) (SURS, 2007).

The situation is more complicated if we look at the results in different regions. The analysis of results at the level of statistical regions showed big differences among them. The most interesting is the Osrednjeslovenska region (a region around the capital of Ljubljana), 
where non-party candidates managed to win 14 out of 26 mayor offices and 135 out of 481 council seats. We are witnessing strong growth in the share of non-party mayors (their share increased from $44 \%$ in 2002 to $53,8 \%$ in 2006) as well as in the share of non-party council members (their share increased from $17,6 \%$ in 2002 to $28,1 \%$ in 2006). Both shares are well above the state average.

The analysis of non-party candidate results at the state and regional levels confirmed our assumption that the thesis of a great political turn in Slovenia at the 2006 local election was based on the results of election in Ljubljana and the Osrednjeslovenska region. If we look at Slovenia as a whole, we cannot talk about big differences between the last and the previous local elections. Nothing spectacular happened on the Slovene political scene. It is true that in some municipalities (especially in capital city of Ljubljana) non-party candidates achieved surprising results but, generally speaking, the role and power of traditional political parties stayed unchanged. 